\title{
Evidence for a Burushaski-Phrygian connection
}

\author{
Ilija Čašule
}

Macquarie University

\begin{abstract}
Based on previous research on the very strong correlations between the Burushaski and Phrygian languages, expanded in this article, we discuss in detail the direct mythological correspondence between Burushaski hargín 'dragon' and Phrygian argwitas 'dragon'. We also contemplate a possible etymology for Indo-European *silVbVr'silver'. The proposition of a historical link between Burushaski and Phrygian is reconsidered, as well as the gene evidence that locates the Burusho within North-Western Indo-European.
\end{abstract}

Keywords: Burushaski, Phrygian, genetic classification, IndoEuropean, mythology, names for 'dragon' and 'silver'.

\section{Introduction}

\subsection{Burushaski studies and Indo-European}

Burushaski is a language-isolate spoken by around 90,000 people (Berger 1990: 567) in the Karakoram area in North-West Pakistan. Its dialectal differentiation is minor. There are three very closely related 
dialects: Hunza and Nager with minimal differences, and the Yasin dialect, which exhibits some differential traits. The earliest, mostly sketchy, material for Burushaski is from the mid to late $19^{\text {th }}$ century (e.g. Cunningham 1854, Hayward 1871, Biddulph 1880, Leitner 1889). The principal sources for Nagar and Hunza Burushaski are Lorimer (1935-1938) and Berger (1998), and for Yasin Burushaski, Zarubin (1927), Berger (1974) and Tiffou-Morin (1989) and TiffouPesot (1989). Edel'man-Klimov's (1970) analysis, revised and summarised in Edel'man (1997) is valuable in the quality of the grammatical description. Berger's (2008) synthesis is very important for the historical phonology and morphology of Burushaski and its internal reconstruction.

We have provided a full correlation of Burushaski with IndoEuropean, outside of Indic and Iranian. In our etymological analyses we have found consistent and systematic lexical, phonological and most importantly, extensive and fundamental grammatical correspondences (the latter are outlined in Čašule (2003b: 69-79) and significantly expanded in the Addendum (8.) to Čašule [2012b]). The Burushaski numeral system is correlated with Indo-European in Čašule (2009b).

In an extensive analysis and comparison of the Burushaski shepherd vocabulary with Indo-European Čašule (2009a) identifies some 30 pastoral terms that are of Indo-European (non-Indo-Iranian) origin in Burushaski, one third of which show direct and specific correspondences with the ancient Balkan substratal layer of shepherd terms in Albanian, Romanian and Aromanian. The correspondences (over 70 of them) in the core vocabulary of names of body parts and functions can be found in Čašule (2003a).

Čašule (2010) focuses on the original Burushaski IndoEuropean vocabulary (over 150 stems with many derivatives) that contains the reflexes of the Indo-European gutturals and correlations are established with various Indo-European branches. The correspondence of the Burushaski kinship terms (32 terms) with IndoEuropean is ana-lysed in Čašule (2013).

On the basis of the analysis of over 500 etymologies (with well over 1000 derivatives) and the highly significant correspon-dences in the grammatical and derivational system (noun stems, all nominal case endings and plural endings, the verbal system and prefixes, suffixes and endings, the complete non-finite verbal system, all of the 
adjectival suffixes, the entire system of demonstratives, personal pronouns, postpositions, adverbs, etc.), in Čašule (2012b) we conclude that Burushaski is genetically related to Indo-European, more specifically with the North-Western Indo-European branch, and a language transformed typologically through contact with an agglutinative and ergative language (also Čašule 2010: 70).

Eric P. Hamp (R), in the review of Čašule (2012a), based on the full body of evidence, and in support of our work, states: "Burushaski is at bottom Indo-European [italics EH] - more correctly in relation to IE or IH, maybe (needs more proof) IB[uru]" and further conjectures: "I have wondered if Burushaski is a creolized derivative; now I ask (Čašule 2009a) is it a shepherd creole ? (as in ancient Britain)". In Hamp (2013: 8-9) he proposes an assured sister relationship between Burushaski and Indo-Hittite.

\subsection{The Phrygian language}

Phrygian is an ancient Balkan language of the people who settled around 1300 BCE in Asia Minor, west of modern Ankara in an area long dominated by the Hitto-Luwian languages. They became a major power in Anatolia and developed a remarkable civilization. According to ancient sources [(Herodotus VIII: 73) (Strabo VIII: 295, q. in Georgiev (1981: 143)], the Phrygians originally came from the Balkan Peninsula, i.e. Macedonia where they lived in the neighbourhood of Thracians and Macedonians. As stated by Georgiev (Ibid): "Long ago the Phrygians occupied a position in the Balkan Peninsula which was central between the Greeks and Macedonians, Mysians and Thracians, Thracians and Pelasgians."

Phrygian is preserved in inscriptions (some 240) dating from the VIII to the III centuries BCE (Old Phrygian) and some 100 inscriptions from the $1^{\text {st }}$ century $\mathrm{CE}$ to the IV century CE. Some scholars believe that the language was extinct by the VII century CE (Mallory-Adams 1997: 418). There are some 50 Phrygian glosses registered by the ancient lexicographers, especially by Hesychius (but also Neoptolemus, Clemens Alexandrinus). The major sources for Phrygian are Haas (1966), Neroznak (1978: 66-156), Brixhe and Lejeune (1984), Diakonoff and Neroznak (1985) and Orel (1997).

Phrygian is an Indo-European language, which according to some Indo-Europeanists (Hamp 1990) belongs to its North-Western branch. Orel (1997) decisively states that Phrygian is a kentum 
language. Diakonoff and Neroznak (1985: 42) indicate that inside the Indo-European linguistic family Phrygian "was decidedly a 'central' language (...) The Phrygian words show the most numerous semantic isoglosses with Greek and Balto-Slavic; if more could be known of Thracian and Pelasgian, and more had been preserved of the original vocabulary of Armenian and Albanian, these languages, no doubt, would also occupy very important places among the nearest relatives of Phrygian."

For further details refer to the extensive study on the numerous and significant Burushaski lexical correspondences in ritual, myth and onomastics with the Phrygian language (Čašule 2004: 50-104), and earlier in Čašule (1998: 21-30). The Phrygian expert Neroznak (1998: $\mathrm{x}$ ) has stated that "the lexical parallels proposed by the author [Čašule] between Burushaski and Phrygian (the most documented of the Paleobalkanic languages) are highly convincing."

In this paper we reconsider and expand what we believe is the strongest evidence for a close correlation between the Burushaski and Phrygian languages.

\section{Etymological analysis of Burushaski hargín and Phrygian argwitas}

\subsection{Preliminaries}

We reproduce for easier reference Berger's (1998 I: 13) table of the phonological system of $\mathrm{Hz} \mathrm{Ng}$ Burushaski, which is valid for the Yasin dialect as well (Ys Bur does not have the phoneme $\mathbf{c h}$ - see also Tiffou-Pesot (1989: 7-9):

\begin{tabular}{|c|c|c|c|c|c|c|c|c|}
\hline \multicolumn{2}{|c|}{$\mathbf{a}$} & & & & & Ș & $\dot{\mathbf{S}}$ & $\mathbf{S}$ \\
\hline & $\mathbf{0}$ & $\mathbf{q h}$ & kh & thh & th & çh & ćh & $\dot{\mathbf{c} h}$ \\
\hline i & $\mathbf{u}$ & $\mathbf{q}$ & $\mathbf{k}$ & $\mathbf{t}$ & $\mathbf{t}$ & c & ć & $\dot{\mathbf{c}}$ \\
\hline & & & & $\begin{array}{l}\mathbf{d} \\
\dot{\dot{n}}\end{array}$ & $\begin{array}{l}\text { d } \\
\text { n }\end{array}$ & $\mathbf{j}$ & $\mathbf{j}$ & $\mathbf{Z}$ \\
\hline
\end{tabular}

y. $\quad$ h $\quad$ l $\quad r$

Notes: 1. All five vowels can be long. 2. Retroflex consonants are marked with an underdot. 3. $\mathbf{w}$ and $\mathbf{y}$ are allophones of $\mathbf{u}$ and $\mathbf{i}$. $4 . \dot{\mathbf{c}}=\mathbf{t s}$ in Lorimer and $\mathbf{c}$ in TiffouPesot (1989). 5. $\dot{\mathbf{g}}=\gamma$ is a voiced fricative velar $/ \mathbf{\gamma} /$. See Čašule (2010) on the 
extensive variation of $\dot{\mathbf{g}}$ and g. $6 . \dot{\mathbf{n}}=[\mathrm{n}]$ or $[\mathrm{ng}][\mathrm{nk}]$. 7. y is a retroflex. 8. A hyphen before a word indicates that it is used only with the pron. prefixes. For the internal variation and alternations see Čašule (2010: 5-19) (2003b: 24-29).

We also reproduce the summary of phonological correspondences between Indo-European and Burushaski (Čašule 2010: 11-12):

$\mathrm{IE} \mathbf{a}>\mathrm{Bur} \mathbf{a}$; IE e $>$ Bur e : Hz, Ng i; IE e (unstr.) > Bur a; IE ē > Bur ée; IE o > Bur ó IE o (unstr.) > Bur a, u; IE $\overline{\mathbf{o}}>$ Bur oó, óo; IE i $>$ Bur I; IE $\mathbf{u}>$ Bur u

$\mathrm{IE}$ ai, ei, oi; eu > Bur a; IE au, ou > Bur u

PIE $\mathbf{h}_{\mathbf{1}^{-}}>$> Bur h-; PIE $\mathbf{h}_{1} \mathbf{e}^{-}>$Bur he-; PIE $\mathbf{h}_{1}$ uner- > Bur har- : -war- : her-

PIE $\mathbf{h}_{2^{-}}>$Bur h-; PIE $\mathbf{h}_{2} \mathbf{e}->$ Bur ha-; PIE $\mathbf{h}_{2} \hat{n}_{\text {ue- }}>$ Bur -we- : -wa-

PIE $\mathbf{h}_{\mathbf{a}^{-}}>$Bur h-; PIE $\mathbf{h}_{\mathrm{a}} \mathbf{e}->\mathbf{h}_{\mathrm{a}} \mathbf{a}->$ Bur ha-; PIE $\mathbf{h}_{\mathbf{4}^{-}}>$Bur h-; PIE $\mathbf{h}_{\mathbf{4}} \mathbf{e}->\mathbf{h}_{\mathbf{4}} \mathbf{a}$ - $>$ Bur ha-

PIE $\mathbf{h}_{3^{-}}>$Bur h-; PIE $\mathbf{h}_{3} \mathbf{e}^{-}>\mathbf{h}_{3} \mathbf{0}^{-}>$Bur ho-; PIE $\mathbf{h}_{\mathbf{x}^{-}}>$Bur h-; PIE $\mathbf{h}_{1} /{ }_{2} \mathbf{i}>$ Bur i-

IE $\mathbf{l}, \mathbf{m}, \mathbf{n}, \mathbf{r}>$ Bur l, m, n, r; IE $\underline{\mathbf{u}}>$ Bur -w/-u; IE un- > Bur b-, also m-; IE $\underline{\mathbf{i}}>$ Bur y/i

IE m > Bur-um, -am; IE no > Bur -un, -an; IE r > Bur -ur, -ar; IE l > Bur-ul, -al

IE $\mathbf{p}>$ Bur p, ph, also b-; IE b > Bur b, also $\mathbf{m}$ (rare); IE bh > Bur b, also $\mathbf{m}$ (rare)

IE $\mathbf{t}>$ Bur $\mathbf{t}$ : th (rare) : $\mathbf{t}$, and d-; IE d > Bur d; IE dh- > Bur d-; IE VdhV > Bur -t-, -țIE $\mathbf{k}>$ Bur $\mathbf{k}: \mathbf{k h}, \mathbf{k}: \mathbf{q}^{1} ;$ IE $\mathbf{k}^{\mathbf{w}}>\operatorname{Bur} \mathbf{k} ; \operatorname{IE} \hat{\mathbf{k}}>\operatorname{Bur} \mathbf{k}: \mathbf{k h}, \mathbf{k}: \mathbf{q}$

IE $\mathbf{g}>$ Bur $\dot{\mathbf{g}}$; IE gh > Bur $\mathbf{g}$; IE $\mathbf{g}^{\mathrm{w}}>$ Bur $\dot{\mathbf{g}}$; IE $\mathbf{g}^{\mathrm{w}} \mathbf{h}>$ Bur $\dot{\mathbf{g}}$; IE $\hat{\mathbf{g}}>$ Bur g, $\mathbf{g} ;$ IE $\hat{\mathbf{g h}}$ - > Bur $\mathbf{g}, \dot{\mathbf{g}}$ IE $\mathbf{s}>$ Bur $\mathbf{s}$ or $\mathbf{s}: \dot{\mathbf{c}}, \dot{\mathbf{c}} \mathbf{h} ; \mathrm{IE} \mathbf{k s}>$ Bur ś

Berger (1998) gives a very careful account of words that may be of Indo-Aryan (including "Sanskritisms") or Iranian origin in Burushaski. His methodology in this respect, apart from his own fieldwork and of others, like Lorimer, Morgenstierne etc, is to look up and check very carefully against the index to Turner's (1966) A Comparative Dictionary of the Indo-Aryan Languages. Wherever there is a match, regardless whether the word is found in Shina, Khowar or anywhere in Indo-Aryan, Berger indicates the lemma number in Turner. Interestingly, 45 Indo-Aryan stems indicated by Berger are not found in Shina or Khowar, but appear in Burushaski and could be in some cases an overlap. They are not taken into account in our Indo-European comparisons. Thus almost all words marked as $\mathrm{T}$ in Berger are excluded from the comparisons with Burushaski, as well as all Urdu matches. Any possible Iranian loanwords have been checked by Berger against Steblin-Kamenskij's (1999, possibly an earlier version) Wakhi etymological dictionary,

\footnotetext{
${ }^{1}$ For a detailed analysis of the alternations k:kh, k:q, k:qh, kh:q, q:qh and $\mathbf{g : g}$, see Čašule (2010: 14-18).
} 
earlier also by the eminent Iranist, Edel'man. ${ }^{2}$ Thus, Berger's indications as to which words and forms are indigenous in Burushaski are accurate and exhaustive.

Furthermore, the Burushaski material has already been sifted carefully for Persian, Urdu and Indo-Aryan loanwords by Berger, Lorimer, Morgenstierne, Zarubin, Edel'man, Klimov, Varma, Tiffou, Buddruss, Tikkanen and other scholars who have studied the language - their findings are conveniently mostly incorporated in Berger (1998). The main source I have used for further comparison with Indo-Aryan is Turner (1966) and with Persian, Steingass (1999) [1892].

To be even more certain, in addition, the Kalasha, Khowar, Dardic, Burushaski and Urdu specialist Elena Bashir of the University of Chicago has looked carefully at all of our material in order to sift again the etymologies for any Indo-Aryan loanwords.

\subsection{Burushaski hargín and Phrygian argwitas}

Burushaski has the word hargín 'dragon, ogre, which comes into being from an ordinary snake, when it becomes big and old' (B 193), in neighbouring Shina 'female snake' (L 196). The word is not found in precisely the same form anywhere else in Indo-Aryan. Jettmar (1975: 285, q. in Zoller 2010: 55) mentions in the Hindukush, but without specific details, Hargin as the name for a constrictor "with a golden mane" (he could well have been referring to the Burushaski word itself). Lorimer (L 196) glosses the Burushaski word with Panj magər maččh. Berger provides the Nager idiomatic expression: in hargín talénu bái 'he listens to no exhortations' ( “he wouldn't heed a hargín").

There is a possibly related mythological creature under the name of Hagrin in Roma mythology which is "a demonic being in the shape of a porcupine with a length of $1 / 2 \mathrm{~m}$ and a breadth of 1 span. Hagrin afflicts sleeping animals, especially those which have been just delivered, by sitting on their back and by having its urine running down over them through which purulent abscesses develop" (Berger 1985: 793, tr. by Zoller 2010: 55, who considers it a loanword into

\footnotetext{
${ }^{2}$ I note here with gratitude the early support for my work by Dž. Edel'man and G.A. Klimov.
} 
Roma). The semantics is however significantly different to the Burushaski meaning and involves metathesis of the liquid.

No one has been able to put forward an Indo-Aryan, Dravidian or Tibetan etymology for these words.

In Čašule (2004: 74) we argued for a strong and direct correspondence of the Burushaski hargín 'dragon' with the Phrygian

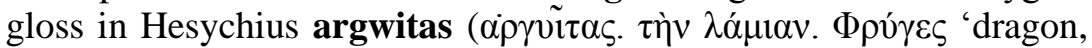
Lamia' (Neroznak 1978: 136). The existing etymology for the Phrygian word is: argwitas $<* \mathbf{h}_{\mathbf{2}} \mathbf{e r} \hat{\mathbf{g}}$-(nt-om) 'white (metal), silver' : OIr argat, MWels aryan(t), Lat argentum, Arma arcat', Luw harkan[za], Av ərəzatəm, OPers ardata, all: 'silver' (M-A 518) (< 'bright, shiny') + *ued- (*ueid-ā-) 'know' or 'see', i.e. 'silverknowing' (Diakonoff, Neroznak 1985: 93). ${ }^{3}$

To explain the semantics, Neroznak (Ibid) indicates that a Lamia in antiquity was a mythological woman-snake and points out that in folkore snake-like monsters often guard a treasure. ${ }^{4}$ The example given above by Jettmar actually brings to the fore the meaning of 'metal' and a slightly different and more general and vague signification. Even though his reference is to a golden and not a silver mane, the same underlying semantics is of 'metal (shiny, bright)'. These in-terpretations make the semantic match between Burushaski and Phrygian exact.

\footnotetext{
${ }^{3}$ There is a tentative indication that Phrygian might have had an initial laryngeal, in a single Phrygian gloss (h)arman 'battle', which Neroznak (1978: 136) relates to OInd árma-ā-h- 'destruction, ruins', from PIE * $\mathbf{h}_{\mathbf{2}} \mathbf{e r h}_{\mathbf{x}^{-}}$'destroy, fall apart; lose' : OInd árdha 'half, part' - in IA without -r-, e.g. Pali, Pkrt aḍ̣ha-, addha-; Lat rārus 'rare', Lith ìrti 'fall apart, dissolve', PSl *oriti, 'destroy' (G 520), Hitt harra'destroy' and with ur- in Mcd urne (se) 'fall down (cliff, stones, building), knock over; pull down; throw to the ground' (RMJ III) (M-A 158). Compare with Bur: Ys do-hór-, $\mathrm{Hz} \mathrm{Ng}$ do-ór- 'fall down (cliff, stones, house)', also d-ur- 'pull down, knock down, hit the ground', Ng also 'ruin, wreck' (Ys d-hor-) (B 308). The Bur verbal prefix d-is used to form secondary intransitives (B 108) or action directed towards the speaker (e.g. in verbs like 'come', 'bring' etc.) (analogous to the semantics of the Slavic pref. and prep. do- 'up to, towards the speaker') < IE *do- (dem. stem). Also Sl da 'and; in order to, yes' and Bur dáa 'again, and, also, moreover; another, other' (B 108), and further dakhíl 'like this, thus', an alternative form of akhíl 'same' (B 110). For comprehensive analyses of the Burushaski d-prefix, see Tiffou (1993), and esp. Tikkanen (1999), and Bashir (2004).

${ }^{4}$ In Bulgarian folkore, the treasure guarded by the Lamia consists of gold, silver and gems (Radenković 2001: 330).
} 
Note also in Burushaski the plant name ${ }^{\mathbf{1}}$ hargál 'Convolvulus arvensis Linn. Ackerwinde' (B 195), Eng "field bindweed, with trumpet-shaped white or pale pink flowers and light brown fruit." It is most likely that it also contains the same Indo-European stem ${ }^{*} \mathbf{h}_{\mathbf{2}} \mathbf{e r g} \mathbf{g}-$ 'white' + a suffix *a-lo.

Phonologically in Burushaski we could have: *hargwitas > *harguitas > *hargit and by association with the form *hargint- > hargín. Another derivational possibility for the Burushaski word is simply from an adjectival form in -en, IE $* \mathbf{h}_{\mathbf{2}} \mathbf{e r g} \mathbf{g}-\mathbf{h}_{\mathbf{1}} \mathbf{e n -}$ 'bright, shiny' [cp. with the IE -en- suffix forming nouns and adjectives (with many variants) (Wat 23) > Bur nom. and adj. suffix -(e)n: Bur meén 'old' (B 285) < IE * $\mathbf{m e h}_{\mathbf{1}}(\mathbf{i})-$ 'grow', Bur ġến 'thief' < $\dot{\mathbf{g}}$ ế- Ys 'steal' (B 175)].

If we take as a starting point the meaning of 'silver-knowing', then Burushaski hargín can be analysed perhaps as a compound word: *harg- 'silver' + gen- > hen- 'know'. The second component

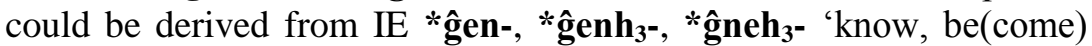
acquainted with, perceive' (M-A 336-337) ${ }^{5}$, preserved in Burushaski gan' 'to appear, seem, be visible' (B 168) (with semantics as in TochB and Bret ), Yasin also -gán- 'see, view' (with semantics closer to Greek) and the negated aqhén "nothing to look at, insignificant, unimpressive, inconspicuous', in Ys also gên 'visible' (B 20). There is also the neg. akhén- 'not to know, not to understand' which is derived internally from Bur hénas 'to know, understand', adj. 'intelligent, wise' (B 196), also adj. akhénas 'ungrateful'. It appears that in these examples we are dealing with minor phonetic variation within one and the same stem. It could be that in hén-, the initial $\mathbf{h}$ - is from an older $* \mathbf{h n}<*$ gin.

For wider mythological connections we refer to Čausidis (2005) who dedicates an entire chapter on the woman-snake. He finds it among the Paeonians (an Ancient Balkan people inhabiting Macedonia, who are considered a population related to the Thracians

\footnotetext{
${ }^{5}$ In Indo-European: OIr ad-gnin- 'recognises', Bret neus 'appearance', OHG kunnan 'know, be able to', Lett zināt 'know', OSl znati 'to know', Arm caneay 'knew', Av zānāiti 'knows', OInd jānăti 'knows, recognises, perceives, understands', Lat (g)nōsco 'know', Gk gignōscō 'learn, know, perceive, observe', Alb njoh 'know', Hitt ganēszi 'recognises' and especially relevant to the Burushaski semantic development, TochB nānā 'appear' < ('come to be known'), TochA knānā 'know' (M-A 336-7).
} 
or the Bryges $/$ Phrygians $^{6}$ ), the Scythians and the Slavs. From these Pontic mythologemes he derives the Swiss and Low Saxon legends of a 'half-woman, half-serpent' who guards the treasures hidden in the caves, called Schlangenjungfrau and weiße Jungfrau. The semantics of 'white' is perhaps relevant to our analysis.

Causidis, notes moreover the legend of Meluzina in the Middle Ages (14th century) considered to be of Celtic provenience. The latter is semantically most interesting for our discussion and semantically very similar to the Burushaski term, because Meluzina periodically gets transformed into a half-woman half-snake and in the end into a flying dragon (Čausidis 2005: 183). Čausidis (2008: 168-169) finds in this regard further Paleobalkanic archaeological evidence from Macedonia, especially the find in Korešnica where thin silver-plated scales have been unearthed, possibly part of an armour, which he considers symbolically related to the zoomorphed women, i.e. to their snake traits.

Under all three interpretations this unique connection between Phrygian argwitas 'dragon' and Burushaski hargín 'dragon' is semantically direct and specific and phonologically precise.

\section{Etymological analysis of Burushaski burí 'silver' and IE *silVbVr- 'silver'}

The Burushaski word for 'silver': burí derives by an identical semantic development as IE $* \mathbf{h}_{\mathbf{2}} \mathbf{e r} \hat{\mathbf{g}}$-ñom 'silver' from $* \mathbf{h}_{\mathbf{2}} \mathbf{e r} \hat{\mathbf{g}}$ 'white', i.e. from Bur burúm 'white' (B 64) which we correlate with IE *bher- 'bright, shining; brown', e.g. the suffixed variant form *bhrū-no-, OEng brūn 'brown', OFr brun 'shining, brown' (Wat 10), which Pokorny correlates with *bherə⿳亠丷厂 - 'to shine; bright, white' (IEW 139) (Wat 11). Under one interpretation (Berneker, Vasmer

\footnotetext{
6 "[The Paeonians] were people that since oldest times settled on the Axius river. Strabo (q. in KatIčić 1976: 117) describes the Paeonians as Thracians, but in another passage links them to the Phrygians. The evidence is so scarce and contradictory that opinions are divided, and some believe they belong to the "Illyrian" complex, others that they are descendants of the Phrygians of Asia Minor or of Hellenic stock. Katičić (Ibid: 116-120) outlines the different views.

${ }^{7}$ Čausidis (p.c.) has alerted me to another possibility, that of the myth of Kadmos searching for gold or silver and Harmonia, who is half-serpent, being the one guarding the treasure, thus 'silver-knowing'.
} 
apud ESSJ III: 42) OChSl bronŭ 'white, variegated', Russ bronyj 'white, variegated' and TochA parno, TochB perne 'shining' are included in this set. Yasin also has burúl 'pale, gray, gray beige colour' (T-M 1989: 14). Note Zarubin's (1927: 339) example with final -n: šilan-ce-bərún 'white-tailed', which could point to an older form *burunum. There is an interesting euphemistic use of burúm as a noun, in the meaning of 'shroud', according to Lorimer (LYs 50) to avoid misfortune or bad luck.

For the possibility that Bur burúm may be ultimately related to IE *bherəĝ - 'white', the Yasin Burushaski form burúxt, berúxt 'secondary colour, for some brown, for others light blue, beige' (Tiffou ms. : 52) is very indicative, as it is directly derivable from IE *bherə⿳亠丷厂 -to $(\mathbf{b h}>\mathbf{b}, \mathbf{e}>\mathbf{e}, \hat{\mathbf{g}}>\mathbf{x}(<\dot{\mathbf{g}})$; cp. with OEng beorht, OHG beraht 'bright' (Wat 11)).

Trubačev (1999: 76) in a chapter devoted to the etymology of the Indo-European words for 'silver' links together the sememes of 'water' - 'silver' - 'mirror'. He argues that the hidden etymology behind the Proto-Slavic, Proto-Baltic and Proto-Germanic names for 'silver' and North Caucasian is that of an Indo-Aryan or Old Indian toponym *śub(h)ri apa 'bright water', semantically paralleling the Armenian, Greek, Latin etc. developments (Trubačev Ibid: 81-82).

It may be that Burushaski can contribute to the long and ongoing discussion of both reconstructed terms for 'silver' in Indo-European.

Burushaski burí could actually continue what would be the second component of the Indo-European word for 'silver': *silVbVr: Ibero-Celt śilaPur (/śilabur/) 'silver', ON silfr 'silver', OEng seolfor 'silver, Goth silubr 'silver', Lith sidābras 'silver', OChS1 sirebro 'silver' [Hamp (1973: 58) gives as the Proto-Slavic form *serbro < *sirəbr-] (M-A 518).

The first component *sil- could be correlated with Bur c̀hil $\mathrm{Hz}$ $\mathrm{Ng}$, (possibly with the alternation u:i/_r,l) Lei. gives $\mathrm{Ng}$ tsil and pl. siliming and silmitshang. Ys: cel 'water; juice, sap' (B 76). [For the alternation $\dot{\mathbf{c}}$ : $\dot{\mathbf{c} h}: \mathbf{s}$, see Čašule (2003b: 28-29)]. Berger relates it to -il- 'to soak, immerse', d-sil-, d-sili- [NH also d-chil- 'make wet (by rain, water), water intensively'], (Ys: di-híl-, pl. $x$ du-húlja-, $y$ dihílja-) (B 212). Note further Bur hánċhil also áṅchil 'water that flows from a wound', as adj. 'watery' (chil 'water') (B 19), the first component from IE $* \mathbf{h}_{\mathbf{2}} \mathbf{e n}$ - 'to draw liquids, draw water' (M-A 169) 
(Wat $4 *$ an-). We can add to this set du-súlġu- 'become fluid,

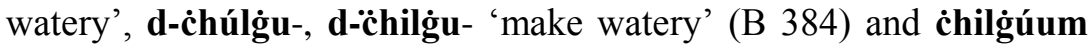
'watery (of soup, etc)' (B 77).

There is also di-ċhí- NH 'rain clouds to appear, to gather' (B 76) and Bur saí NH 'a small spring' (B 372) which could be related and may provide evidence that $\mathbf{c}$ hil is an extended stem, as in IndoEuropean below (possibly with a velar extension: Bur cak 'sluice, sluice-board') (B 68).

There is a very likely correlation with IE *suel-, *sul- 'to wet, to moisten; to flow; (as a noun) liquid, moisture' (in IEW 912-3: *seu-, *seù- : sū- 'juice', seu-d- in OSax be-sūtian 'make dirty', OIcl sut 'a worry', sȳta 'to mourn', also with a guttural formant: *seuk-, *sŭk- and *sūk, *seug-) : Mann 1984-1987: 1334 *sūl 'liquor, issue, sludge', 1334-1335 *sulu - 'fluid; (to flow)', (BK U191) e.g. Lith sulà 'sap', OPrus sulo 'curdled milk', OHG sol 'mud, puddle', OIcl sulla 'to swill', OE swillan, swilian 'to flood with water so as to wash or rinse, to drink in large quantities', sol 'mud, wet sand', syl 'wallowing place, miry place', sylian 'to make muddy or dirty, to pollute', Skt súrā 'spiritous liquor, wine', Av hurā 'drink' etc. Most etymologists consider that Alb shi 'rain' also belongs here (see the discussion in Huld 1984:113 and Hamp, apud Huld, who includes here OPruss soye and TochA swase, TochB swese, all: 'rain'). M-A (477) propose a stem ${ }^{*} \mathbf{s u h h}_{\mathbf{x}^{-}}$'rain', which they believe need not be connected with *seu- 'to press, juice'. This stem is considered also within the Nostratic comparisons, although apart from Indo-European it is only registered in the Kartvelian languages, where it is found only as an adjectival and verbal form (i.e. 'wet, moist', 'to wet, to moisten') and not as a noun. Perhaps Thracian zelas, zilas 'wine' (Neroznak 1978: 47) also belongs here.

This etymological analysis could possibly explain the reason why we have different formants (-d in Baltic, $-\mathbf{r}$ in Slavic and $\mathbf{- l}$ in Germanic) in the reflexes of IE *silVbVr-.

We can suggest very tentatively that Burushaski perhaps provides evidence that IE *silVbVr-'silver' may be a compound noun, consisting of *sul- : *sil- 'water' + *bhru- 'white', i.e with a semantics as 'white [shining] as water'. Similar compounds with chil as the first component are very productive in Burushaski. Note chílbupur "pea-sized balls of dough cooked in water, "Spätzle" (B 77), or ċhilphú 'water and fire' ('climate') (phú 'fire', also of IE 
origin $^{8}$ ) or ċhilpées NH 'small spring on the hillside' (B 77) and esp. Ys cel-haralt 'fine cloud' (lit. 'water-rain') (BYS 136). There is also a verbal form Ys céltikin- (L certikin-) 'to mourn (cry after) the deceased, before putting him in the ground' (B 137), i.e. cél-tik-in(tik 'ground'), literally 'water-ground-put'. Perhaps most relevant to our analysis is Ys célcerer 'dirty water' (BYs 136) (lit. 'water-dirty') which would have been opposed to *'e/il-bur 'water-white/bright' > 'silver'.

Trubačev (1999: 78) states that in Homer we learn that the "birthplace of silver" was the Pontic town of 'A $\lambda \hat{v} \beta \eta$, which Schrader (1901: 764) derives from $* \Sigma \alpha \lambda u ́ \beta \eta$, which appears to give support to our reconstruction.

Bearing in mind the strong Phrygian connection with Burushaski, this analysis might possibly shed more light on the origin of silver among the Indo-Europeans - possibly Central and Eastern Anatolia?

\section{Note on other Phrygian-Burushaski correspondences}

An objection could be raised that the connection between Burushaski hargín 'dragon' and Phrygian argwitas 'dragon' even if direct, semantically precise and strong is an isolated one. This is not at all the case.

As noted, other related correspondences have been discussed in Čašule (2004). It is highly significant that in Burushaski there are three terms correlatable with the Phrygian Great Mother.

We reiterate here the rather close, precise and important link in the Burushaski kinship term zizí (pl. zizícaro) 'Mother! Form of address used only in the families of the Rajas and (in Nagir) Saiyids. Foster mothers, being of lower rank, are called "mama". The corresponding term to zizí for father is babá (B 27). This term is used properly only in Royal Families (L 63). Berger points to U bābā. These terms are said to have come down from the time of Alexander the Great (Lorimer 1935: II 30.15; 238.6). They are in use in Shina

\footnotetext{
${ }^{8}$ Bur phu 'fire' (B 334), phu ét- 'make a fire' (B 335), Ys phuréś -t- 'cook; slander' (BYs 171) from IE *peūōr, *pŭr 'fire', (gen. sg.) *pu-n-és < older *peHū- (M-A 201).
} 
and Khowar and in Balti zizi (B also zi) and bawa (L 391), yet no one has been able to provide an Indo-Aryan, Dravidian or Tibetan etymological explanation for zizí.

We have compared Bur zizí with Phrg Zizimene - "The epithet of Zizimene is frequently used to designate the Great Mother in various centres of Asia Minor." (Gasparro 35, also Calder 1912: 7274). "In an altar from Sizma, a village of Lycaonia situated near Iconium and Laodicea, whose four faces bear reliefs representing deities and inscriptions on side D, we read the dedication Metri Zizimmēnē. Ramsay believed it is a dialectal form of Dindymene, in at least one case the Mother of the Gods is explicitly called Zizimene." (For further discussion, see Čašule (2004: 86, ex. 24). Considering the close correspondence between Phrygian and Burushaski in the fields of ritual, myth, burial and onomastics and the use of Burushaski zizí by the Royal Families, this is a correlation with some merit. If the Burushaski word preserves an ancient "cultic" term for the Great Mother it could have easily been the ultimate source for Shina, Khowar and Balti.

The Phrygian epithet for the Great Mother Apa-, dat. sg. Apai and Appas also Appē indigenous Phrygian names of Late Anatolian type (Orel 1997: 414) (Zgusta 1964: 73-74) is preserved in the Burushaski epithet Ápi in Ápi Dadií 'name of a fairy' (B 487).

A very important indication that Burushaski ultimately may belong to the Balkan-Pontic-Asia Minor complex is the preservation of Phrg kubela 'horse', matar kubeleya 'mother of horses', also the name of Cybele ${ }^{9}$, the Phrygian deification of the Earth Mother, related to Indo-European *kab-, *kabula- 'horse', Thrac *kabūla > Gk kabállēs 'working horse', from Thrac > OSl kobyla 'mare', and > Lat caballus 'gelding, work horse, horse' and late Lat cabō in glosses "caballus, caballus magnus, equus castratus", Gk Hesychius kábēlos 'castrated'. Buck (1949: 16) considers the Indo-European words to be certainly loanwords of "ethnic origin" (Anatolian or Balkan), probably with an original meaning of 'gelding'.

\footnotetext{
${ }^{9}$ There is a curious, most likely coincidental Burushaski formulaic expression which may contain the name: qubili manas (only in L 300) 'to swing', as explained by Lorimer "women and children swing during the Nauroz celebration" and qubili gaša "said by the person on the ground as he pushes the other up on the swing" (? go up to qubili).
} 
Significantly in Burushaski (Ys) we find kabút 'white horse' (Tiffou-Morin: 1989: 33) and Hz Ng kabulék 'roof-posts' (B 239, q. K 120), with almost identical development (from *kabuliko), as in PSl *kobylica (<*kabūlíko) 'a pole for carrying loads on the shoulder', 'beam of scales', 'trestle', 'horse-tree', 'saw-horse', 'wisp', and esp. 'scaffolding, supporting beams' (ESSJ X: 98) and PS1 *koby-lŭka 'pole for carrying loads' (ESSJ X:100). In this example, the Burushaski form correlates more closely phonologically with Thracian and Slavic.

We reconsider briefly some of the other correspondences in myth, ritual and burial between Burushaski and Phrygian. For example: Phrg itimbos 'Bacchic dance' (Haas 165) : Bur țimgiúr, țimzál man- 'to dance well, to show off' (and țimbáao :t- 'to discharge a gun, let off' (B 445); Phrg iman 'cultic substitute, imitation, image, model' (Orel 1997: 432) : Bur imán 'duplicate,

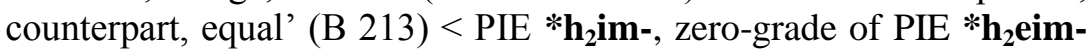
'copy' (Wat 2) (Orel 432); Phrg bat(an) '(part of) religious monument, (part of tombstone)' (Orel 419) : Bur bat pl. batén 'flat stone (for putting over a water channel, or over a grave' (B 43) (Will 21), Lorimer (L 73) indicates that 3 or 4 flat thin stones are normally put over the grave cavity; Phrg goutārion 'sarcophagus' (Haas 137, 163) : Bur gúțas 'corpse'; Phrg manka 'gravestone, memorial' (Orel 443) : Bur man 'earth platform, sleeping and sitting platforms in house, (stone) dais; mound over grave' (B 278) (in Will 85 also: 'a cement slab or dirt mound placed over a grave'); Phrg thalámai 'places consecrated for the cultic practice of the Galli' [the castrated priests of Cybele] (Gasparro 1985: 53) : Bur Tálmuśi Bat 'stone where the witches cut up their sacrifices', Tálmuśi Dadií 'name of a fairy' (B 509) etc. (for the complete etymological analysis, see Čašule 2004: 73-86).

Consider from the Phrygian inscriptions dumas, for which Haas (142) suggests a meaning of '(funerary) mound', whereas Diakonoff and Neroznak (104) propose 'village, municipality'. The Phrygian word is also used in Greek inscriptions in Asia Minor with the meaning of 'cult union'. It has been derived from IE *dhō-mo'pile', the o-grade suffixed form of IE *dhē- 'to set, to put' (Wat 17): Gk thomós 'pile', OIr dam 'troop' and with semantic changes in Goth dōm-s 'objection, decision' and OInd dhāman 'a multitude (of servants)' (Neroznak 128) (Orel 425) (IEW 238). 
The Phrygian word can be phonetically and semantically correlated with Burushaski dúuman 'pile, heap' (B 127) $(<*$ dhōmen- ? or *dhōm-an). The Old Indian form dhāman (in Turner 6785: 'dwelling place', 'sucking') is semantically too removed to have been the source of the Burushaski word, which keeps the core meaning. It is important that the IE stem *dhē- is well represented in Burushaski: note also :t- 'do, make, build' (B 413) and doók man'- 'put, set down, build' (B 121) (< IE *dhō-k- 'do, make, put') (IEW 235). The Burushaski verb -t- is, as in Phrygian, most significantly also found with an e- augment as ét-, stable in verbal compounds (B I:19.36) (L 39) (the augment does not occur with other verbs).

Note also the very close correspondences between Burushaski and Phrygian names:

Phrg Arkiaewais (Orel 415) : Bur Argumaáq (B 486)

Phrg Bakio- (Orel 419) : Bur Bákuċ (B 488)

Phrg Ballion (Arkwright 50) : Bur Balíṣa (Berger segments ? Bali- + U šāh) (B 488).

Phrg Basa, Basos, Bastos (Petrova 182) : Bur Basúu (B 489)

Phrg Beudos (Orel 420) : Bur Bádi (B 488) (B 492)

Phrg Boras, Boros, Boriskos (Arkwright 51) : Bur Boroṣ (B 490)

Phrg Botíeion (<*Botios) (Arkwright 59) : Bur Bóți (B 490)

Phrg /AncMcd Brygos, AncMcd Byrginos (Petrova 182) : Bur Birgáo, Birgán (B 490)

Phrg Dado, Dadés (Orel 421) : Bur Dadóko, Dadií (B 493)

Phrg Dudes (Petrova 185) : Bur Dúdo (B 494)

Phrg/Gk Ekatēas (Orel 427) : Bur Katiš Malčučo (L 430)

Phrg Gaiteas (Drew-Bear 383) : Bur Ǵatósin (B 496)

Phrg Kuliyas (Orel 439) : Bur Kulió, Kulí (B 501)

Phrg Lile, Lillia (Hitt Lilli) (Orel 441) : Bur Lilí (B 501)

Phrg Mamas (Zgusta 282-282) : Bur Mamú, Mamúro (B 502)

Phrg Mane, Mani (Orel 443): Bur Máni, Máno (B 502)

Phrg Nana (Orel 447) : Bur Nané Munúno (B 504)

Phrg/Gk Nikōn (Drew-Bear 388) : Bur Níko (B 504)

Phrg Pukros (Orel 455) : Bur Phugóóri (B 32-33)

Gk/Phrg Sīlēnốs (Liddell-Scott 1598, Chantraine 1003) : Bur Silúm

(B 507)

Phrg Tuti (Hitt Tuttu) (Orel 465) : Bur Túto (B 510)

Phrg Tolos (Orel 464) : Bur Thol (B 510)

For the full and detailed discussion, see Čašule (2004: 88-92). 
Outside the semantic field of myth and ritual there are many correspondences between Burushaski and Phrygian. Almost $80 \%$ of the attested Phrygian glosses find correlation with Burushaski and every third word in the inscriptions is also preserved in Burushaski.

Consider, for example the direct connection between Bur úrunas 'morning star, Venus' (BYs 184) which we derive from IE *uer-2 'raise, high place, top, high' (IEW 1150), and NPhrg oruenos (from the inscriptions) interpreted as 'high, elevated' (Neroznak 1978: 152) Phrg uranios 'celestial' (D-N 140), also Gk uránios 'in the sky, as high as the sky' (Diakonoff-Neroznak 1985: 140). From the same Indo-European stem we have the correspondence between Bur -úri, Hay uru 'summit, top, peak, crest, ridge' (B 66) and the Phrygian gloss orū 'upwards, on top' (Neroznak 1978: 151).

There is also the precise and direct correspondence between the Phrygian gloss mā 'Phrygian call to cattle' (Neroznak 1978: 150) interpreted as an interjection (prominent and specific to be recorded by the ancient lexicographers) and the Burushaski interjection máha 'come! - a call to a horse' (B 275). Interjections of this type are generally culture-specific, even if they have an expressive component (Bashir p.c.).

It is remarkable that both Burushaski and Phrygian being "kentum" languages should share one "satem" word belonging to the basic vocabulary. Consider Burushaski -sán 'chin' (B 373-374), if from IE * ĝenu- 'jaw, chin, cheek', e.g. Gk geneiás 'beard, chin, cheek', Lat gena 'cheek', OInd hánu-s 'jaw', Av zānu 'jaw', Cymr gen 'cheek, chin', OEng cin(n) 'chin' (IEW 381) which corresponds with Phrygian: azen(wa) 'jaws', azenu 'beard' (D-N 96). It may be that this word is a borrowing in both languages.

A rather important identical grammatical element shared with Phrygian is the Burushaski conjunction ke 'also, too, and; it also seems to serve as an emphasising particle' (...) "ke frequently follows immediately after indefinite pronouns and indefinite adverbs of time and place" (i.e. enclitic, same as in Indo-European) (L 231-232) (B 244) from IE * $\mathbf{k}^{\mathbf{w}} \mathbf{e}$ 'and (enclitic)' - Phrygian ke 'and, also, but', Gk te, Myc Gk -qe, Goth -h, Arm -k', Hitt -ki 'and', Lat que 'and; generalising particle', OInd ca, Av ča 'and' (IEW 519) (see Čašule 1998: 26). 
In grammar we find an indicative shared development from IE *mn-, *men- 'remain, stay' ( $>$ 'be, become') (IEW 729) : Bur man'10 'be, become, turn into; become (absolute) $>$ come into existence, occur, take place; belong to; proceed to, be about to; be necessary to do s-thing or for s-thing to be done' (B 278). For the relevance of the Indo-European middle passive for the understanding of the development of the Burushaski verbal system note further the very productive use of Bur verb man-, also used in forming periphrastic verbal constructions (B 278) in compound verbs, in the sense 'become', 'be' (or sometimes semantically empty) + another stem, e.g. hop -mán- 'be puffed up, (of body parts) swell up suddenly', lam, lálam man- 'shine, burn, light up; to beam' (B 261), háak man''help s-one in their work' (B 184). While this is a widespread pattern and structure in the languages surrounding Burushaski (Bashir p.c.), it seems to point also materially to the functions of the IE suffix -menoor -mno- in the passive middle, e.g. Gk epómenos 'following' (Phrg gegrimenos 'written' (Diakonoff-Neroznak 1985: 111), which has also been derived from the same IE *men- 'remain' (Szemerényi 1996: 320-321) and is a shared innovation in Greek and Phrygian.

Further examples where the two languages correspond closely and match up directly within Indo-European include: -Phrg gloss

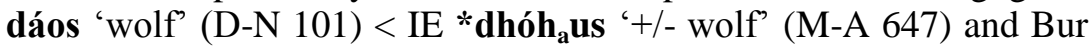
diucón, $\mathrm{L}$ : diusón $\mathrm{pl}$. diućóyu 'hound-like wild animal' and diú 'lynx' (BYs 142). In the Burushaski form there appears to be a contamination between the expression di ét- 'to set a hound loose on s-one' (B 118) and a nominal form *du(s); -Phrg gloss bambalon 'penis' < IE *bhal-bhal < *bhol- 'swell (spec. of genitalia)' (N 139) (M-A 71) and Bur bambulá 'male' (B 35); Phrg gloss attagos 'goat' (D-N 95) : Bur thugár 'he-goat' (B 442), dágar 'wether' (B 128); Phrg gloss bedu 'well(?), spring, jug (?)' (D-N 98) 'vessel, spring(?)'

\footnotetext{
${ }^{10}$ Bur man' is a very productive verb. Within developments from IE *men- 'remain, stay' (a widespread and old IE stem), semantically the correspondence is direct with TochAB mäsk- (< *mn-sk̂ke/o-) 'be, become', and further Gk ménō 'stand fast, remain; await', Lat maneō 'remain', Arm mnam 'remain, expect' and with other semantic developments OIr ainmne 'duty', Wels amynedd 'duty' (note above the Burushaski meaning 'to be necessary to do s-thing'), also OInd man- 'delay, stand still' and Hitt mimma 'refuse', which is a widespread and old stem in IE (M-A 482). Note here also the earliest Hittite names (XVIII century BC) of the type Harsumnuman 'of Harsumna', considered to have the same IE element - in this sense the possessive meaning in Burushaski ('belong to') corresponds very well.
} 
(N 139), and Bur baḍalík (also in Sh baḍulík) 'a small metal bowl (for drinking from)' (B 29, who gives for Nager the meaning 'big vessel for water') < *bad-al-ik (both -al and -ik are suffixal elements); Phrg gloss bagaios 'crazy, also Phrygian Zeus' (N 137138) : Bur bagálta- 'to be mad, to go mad' (B 30) (-lta- is a suffix as in harált 'rain' from hará- 'flow, urinate' (B 192), both possibly from IE *bhēgh- : *bhōgh- 'to quarrel, dispute' (> 'wicked, warlike, awkward, mischievous') etc. There is a remarkable semantic and phonological match between the Phrygian gloss kimeros "voũ $\varsigma$ " 'reason; sense, thought, desire, intention, will' (N 147) and Burushaski Ys xumár, xumór, $\mathrm{Hz} \mathrm{Ng}$ qhimóor 'desire, longing, lust, appetite' (B 356) - in both cases a word of unknown origin.

On a concluding note, we believe it is not insignificant that we have a close and precise correspondence between Phrygian and Burushaski in the word for "writing" in a form of great antiquity:

We have Bur girmín- 'to write', girmínum 'inscription, i.e. certificate' (pp. nikírmin $\mathrm{Hz} \mathrm{Ng}$, Ganesh nukírmin) (B 155) (with the Bur b >/: $\mathbf{m}$ change, see Berger 2008: 3.21); for the full discussion, see Čašule (2004: 71-72). Note the alternation $\mathbf{k}: \mathbf{g}^{11}$. Morgenstierne (L, I:XXXI) noted the similarity between the Burushaski verb and the Armenian gri 'writing', but dismissed it on the grounds of the improbability of it being an old borrowing.

The Burushaski verb can be derived from IE $* \mathbf{g}\left({ }^{w}\right) \mathbf{h r e ̄ i}$ - : * $\mathbf{g}($ ')hrī- 'smear, scratch', and thus cognate with Phrg gegrimenos, gegrimena 'written, inscribed', Arm gream 'write', Gk khríō 'I write' (D-N 1985: 111) (Haas 237) or IE *gerbh- 'to scratch' : e.g. Gk graphein 'to scratch, draw, write' (Wat 27) (IEW 392: *gerebh-). Especially interesting is Arom zgîrma, zgrîma, sgrîma 'to scratch, to scrape' believed to originate from the Balkan substratum (Illyes 1988: 237).

11 In both Phrygian and Burushaski there is evidence that points to a Lautverschiebung in their historical phonology, but this is a topic that cannot be discussed properly here. In Burushaski, in many cases, voiceless stops are voiced in the anlaut or have both voiced and voiceless allophones $-\mathbf{p}->\mathbf{b}-, \mathbf{k}->\mathbf{g}-, \mathbf{t}-\mathbf{>} \mathbf{d}-$. See the examples and discussion of this alternation/change in Berger (2008: 3.11), who treats them as internal variation, and on the historical plane Čašule (2010: 8-10). 


\section{Extralinguistic considerations}

An objection could be levelled that it would be impossible for the Phrygians to turn up in North Western Pakistan, so far away from Asia Minor. If they had been evidenced in the vicinity of today's Burushaski speaking areas, the correspondences found would be accepted more easily. Yet, there is evidence of an eastward migration of the Phrygians.

Most recently, the eminent Russian archaeologist L. S. Klein (2007, 2010) has published two major studies on Indo-European ancient migrations. He devotes an entire chapter (Klein 2007: 108120) specifically to the migrations of the Phrygians / Bryges from the Balkans. On the basis of archaeological evidence, historical sources, some linguistic aspects and mythical and religious comparisons he traces their movement from Macedonia and its north via Asia Minor, Central Asia and most importantly all the way to Swat in NorthWestern Pakistan, very close to the Burushaski speaking areas. He argues for an early contact between Phrygian and Sanskrit. He notes that Indian scholars (Kosambi: 1968: 89-90, q. in Klein 116) have long ago linked Bhrigu, the carrier of fire and the son of the Indian god Varuna, with the Phrygians. In light of new evidence, Klein believes these claims should be taken very seriously.

Sidky (1999) suggests a possible later intrusion of the Phrygians into the Burushaski speaking areas of NW Pakistan. He provides extralinguistic evidence for the possibility of Phrygian presence and interaction in the area during the Bactrian kingdom, esp. in the face of Euthydemus, the king of Bactria, who came from Asia Minor. As Sidky (1999: 246) points out "men from Thrace, Phrygia (and elsewhere in Asia Minor) as well as Mesopotamia, were certainly among those who came to Bactria as colonists during the Hellenistic period (...) It is conceivable that some of these colonists, or their descendants, may have found their way to the Hunza valley."

Genetic studies appear to confirm our findings. In a major genetic study (Oefner et al. 2013: 841) the authors conclude that all Burushaski samples (20) in the Y-chromosome microsatellites clusters group distinctly and consistently with Italian and Russian Y chromosomes, and not with the Pakistani samples. They cite in some detail our work on Burushaski and Phrygian indicating that the genetic make up they have investigated supports directly our 
conclusions, i.e. that genetically Burushaski fits within North-Western Indo-European, just as Phrygian.

They also cite Mansoor et al. (2004) which is a previous study of 113 autosomal microsatellite in extant Pakistani and Greek populations who concluded "that there was evidence for a southeastern European contribution to the gene pool of the Burusho and the Pathan that probably predated the invasion of the Indian subcontinent in 327-323 BC by Alexander the Great," (Ibid 839).

\section{Conclusions}

The unique correspondence within Indo-European between Burushaski hargín 'dragon, ogre, which comes into being from an ordinary snake, when it becomes big and old', (Sh 'female snake') and Phrygian argwitas 'dragon, Lamia [mythological woman-snake]' (from IE * $\mathbf{h}_{2}$ erĝ-nt-om 'silver'), is a solid and precise one. The fact that it is a longer phonological and very specific semantic correlation rules out chance.

It may also be the case that the Burushaski material provides us with a possible solution for the etymology of the Indo-European term for 'silver': *silVbVr- may be a compound noun, consisting of IE *sul- : *sil- 'water, liquid' + *bhru- 'white', i.e with a semantics as 'white [shining] as water', or rather 'water-white'.

All the numerous correspondences in myth, cult and ritual, in onomastics (22 personal names) and in basic vocabulary between Burushaski and Phrygian, many of them unique within IndoEuropean, argue very convincingly for a strong relationship between the two languages. Not least, Burushaski preserves three terms associated with the Phrygian supreme goddess, the Great Mother Kubela. As noted, almost $80 \%$ of the attested Phrygian glosses find correlation with Burushaski and the latter preserves every third word from the inscriptions.

Whatever the depth of this connection, our comparative analysis with Phrygian strengthens significantly the position that the Burushaski language belongs to the North-Western branch of IndoEuropean.

Further comparison of the Phrygian texts with Burushaski will shed more light on the close relationship between the two languages. 


\section{Abbreviations of languages and dialects}

Alb - Albanian, Arm - Armenian, Arom - Aromanian, Av Avestan, Balt - Baltic, Bret - Breton, Bur - Burushaski, Celt Celtic, Celt-Iber - Ibero-Celtic, Cymr - Cymric, Eng - English, Gk - Greek, Goth - Gothic, Grm - German, Grmc - Germanic, H Hindi, Hitt - Hittite, Hz - Hunza dialect of Burushaski, IA - IndoAryan, IE - Indo-European, IH - Indo-Hittite, Ind - Indian, Ir Irish, Irn - Iranian, Itl - Italic, Khw - Khowar, Kshm - Kashmiri, Lat - Latin, Lett - Lettish, Lith - Lithuanian, Mcd - Macedonian, Myc Gk - Mycenean Greek, Ng - Nager dialect of Burushaski, NH Nasiruddin Hunzai, Berger's Burushaski informant, NPers - New Persian, NPhrg - New Phrygian, NWels - New Welsh, OChSl - Old Church Slavonic, OEng - Old English, OHG - Old High German, OInd - Old Indian, ON - Old Norse , Panj - Panjābī, Pers Persian, Phrg - Phrygian, PSl - Proto-Slavic, Russ - Russian, Sh Shina, Skt - Sanskrit, Sl - Slavic, Soghd - Soghdian, Thrac Thracian, Toch A, Toch B - Tocharian A, Tocharian B, U - Urdu, Wels - Welsh, Ys - Yasin dialect of Burushaski.

\section{Abbreviations of sources cited}

B = Berger, H. 1998; BYs = Berger, H. 1974; Cunn = Cunningham, A. $1854 ;$ DC = Tiffou, E. and Y.C. Morin. 1989; E-K = Edel'man, D. I. and G. A. Klimov 1970; G = Gluhak 1993; Hay = Hayward 1871; IEW = Pokorny, Julius. 1959; Lei = Leitner, 1889; L = Lorimer, D. L.R. 1938; LYs = Lorimer, D. L.R. 1962; M-A = Mallory, J.P. and D.Q. Adams (eds.). 1997; RMJ = Rečnik (1961-1966), T = Turner, R. L. 1966; T-M = Tiffou, E. and Y. C. Morin 1989; T-P = Tiffou, E. and J. Pesot. 1989; Wat = Watkins, C. 2000; Will = Willson, S. R. 1999; W-I-S = Wodko, D. S., B. Islinger and C. Schneider. 2008. 


\section{References}

Arkwright, W. G. 1918. Lycian and Phrygian names. The Journal of Hellenic Studies, Vol. 38: 45-73.

Bashir, Elena. 2004. Le préfixe d- en Bourouchaski: deixis et point de référence. In: Tiffou, É. (ed.) Bourouchaskiana. Bibliothèque des Cahiers de l'Institut de Linguistique de Louvain. No. 113: 17-62. (French translation of "The d-prefix in Burushaski: Deixis and Viewpoint" originally presented at the 36th International Congress of Asian and North African Studies, Montreal, 2000).

Berger, Hermann. 1974. Das Yasin Burushaski (Werchikwar). Wiesbaden: Otto Harrassowitz.

1985. Mythologie der Zigeuner. In Haussig, Walter (ed.) Wörterbuch der Mythologie. Bd. 5: Götter und Mythen des indischen Subkontinents. Stuttgart: Klett-Cotta: 775-826).

1990. Burushaski in Encyclopaedia Iranica. Ehsan Yarshater ed. London and New York: Routledge and Kegan Paul. Vol IV: 567-568.

1998. Die Burushaski-Sprache von Hunza und Nager. Teil I. Grammatik. Teil II. Texte. Teil III. Wörterbuch. BurushaskiDeutsch; Deutsch-Burushaski. Neuindische Studien 13. Wiesbaden: Harrassowitz Verlag.

2008. Beiträge zur historischen Laut- und Formenlehre des Burushaski. Neuindische Studien 15. Wiesbaden: Harrassowitz Verlag.

Biddulph, J. 1880/1986. Tribes of the Hindoo Koosh. Calcutta: Government Printing Office. (Reprinted 1986: Lahore: Ali Kamran Publishers.)

Bomhard, A., Kerns, I.C. 1994. The Nostratic Macrofamily: A Study in Distant Linguistic Relationship. New York: Mouton de Gruyter.

Brixhe, C. and M. Lejeune. 1984. Corpus des inscriptions paléophrygiennes. Paris: Recherche sur les civilisations. 
Buck, C. D. 1949. A Dictionary of Selected Synonyms in the Principal Indo-European Languages. Chicago-London: University of Chicago Press.

Calder, W.M. 1912. Inscriptions d'Iconium. RPhLH XXXVI: 72-74 (in Gasparro 1985).

Čašule, Ilija. 1998. Basic Burushaski Etymologies. (The IndoEuropean and Paleobalkanic Affinities of Burushaski). MunichNewcastle: Lincom Europa.

2003a. Burushaski Names of Body Parts of Indo-European Origin. Central Asiatic Journal. 47/1: 15-74.

2003b. Evidence for the Indo-European Laryngeals in Burushaski and Its Genetic Affiliation with Indo-European. The Journal of Indo-European Studies. 31/1-2: 21-86.

2004. Burushaski-Phrygian Lexical Correspondences in Ritual, Myth, Burial and Onomastics. Central Asiatic Journal.48/1: 50-104.

2009a. Burushaski Shepherd Vocabulary of Indo-European Origin. Acta Orientalia. Vol. 70: 147-195.

2009b. Burushaski Numerals of Indo-European Origin. Central Asiatic Journal. 53/2: 163-183.

2010. Burushaski as an Indo-European "Kentum" Language: Reflexes of the Indo-European Gutturals in Burushaski. Munich: Lincom $\mathrm{GmbH}$.

2012a. Macedonian and South Slavic Lexical Correspondences with Burushaski. Balkanistica. Vol. 25: 221-256.

2012b. Correlation of the Burushaski Pronominal System with Indo-European and Phonological and Grammatical Evidence for a Genetic Relationship. The Journal of Indo-European Studies. Vol. 40, Numbers 1\&2, 59-154.

2013. Burushaski kinship terminology of Indo-European origin. In Owen-Smith, Thomas \& Nathan Hill (eds). TransHimalayan Linguistics, Historical and Descriptive Linguistics of the Himalayan Area. Series: Trends in Linguistics. Studies 
and Monographs [TiLSM] 266, New York: De Gruyter, 181220.

Čausidis, Nikos. 2005. Kosmološki sliki. Simbolizacija i mitologizacija na kosmosot vo likovniot medium. Vol. 1 (text), Vol. 2 (illustrations, catalogue). (Summary: N. Čausidis, Cosmological Images. Symbolisation and Mythologisation of the Cos-mos in the Pictorial Medium). Skopje. 2008 [2004-2006]. The Trebenište crater and the myth of Kadmus and Harmonia. Macedoniae Acta Archaeologica. 19: $157-175$.

Chantraine, P. 1974. Dictionnaire étymologique de la langue grecque. Paris: Klincksieck.

Cunningham, A. 1854. Ladak, Physical, Statistical and Historical: With Notes on the Surrounding Country. London. [pp 398-418 a short word list].

Diakonoff, I. M., Neroznak, V. P. 1985. Phrygian. New York: Caravan Books Delmar.

Drew-Bear, T., C.M. Thomas, M. Yildizturan. 1999. Phrygian Votive Steles. Ankara: Ministry of Culture, Museum of Anatolian Civilizations.

Edel'man, Dž. I. 1997. Burušaski jazyk. In: Volodin, A.P. et al. Paleoaziatskie jazyki. Series Jazyki mira : 204-220. Rosiijskaja akademija nauk. Moscow: Indrik. Edel'man, Dž. I., Klimov, G. A. 1970. Jazyk burušaski. Moscow: Nauka.

Gasparro, Julia Sfameni. 1985. Soteriology and Mystic Aspects in the Cult of Cybele and Attis. Leiden: E.J. Brill.

Georgiev, V. 1981. Introduction to the History of the Indo-European Languages. Sofia: Bulgarian Academy of Sciences.

Gluhak, Alemko. 1993. Hrvatski etimološki rječnik. Zagreb: A. Cesarec.

Haas, Otto. 1966. Die phrygischen Sprachdenkmäler. Sofia: Bulgarian Academy of Sciences. 
Hamp, Eric P. 1973. Lith sidâbras, OCS srĕbro. Baltistica. IX: 1. 5758.

1990. The pre-Indo-European language of northern (central) Europe. In Markey, T. L. and Greppin, J. A. C. (eds). When Worlds Collide: Indo-Europeans and Pre-Indo-Europeans. Ann Arbor: Karoma. 291-305.

2013. The expansion of the Indo-European languages: An Indo-Europeanist's evolving view. Sino-Platonic Papers. Number 239.

Hayward, G.W. 1871. Hunza and Nager, and Yassin. Vocabularies. Journal of the Royal Asiatic Society. Vol. XLI. p.18ff.

Huld, Martin E. 1984. Basic Albanian Etymologies. Columbus: Slavica.

Illyes, Elemér. 1988. Ethnic Continuity in the Carpatho-Danubian Area. Eastern European Monographs. CCXIIX. New York: Columbia University Press.

Jettmar, Karl. 1975. Die Religionen des Hindukusch. Die Religionen der Menschheit. Bd. 4, 1. Stuttgart: Kohlhammer.

Katičić, Radoslav. 1976. Ancient Languages of the Balkans. The Hague: Mouton.

Klein, Lev S. 2007. Drevnie migracii i proisxoždenie indoevropejskix narodov. St. Peterburg.

2010. Vremja kentavrov. Stepnaja prarodina grekov i ariev. Evroazija: St. Peterburg.

Kosambi, D. D. 1965. The Culture and Civilisation of Ancient India in Historical Outline. London: Routledge and Paul.

Leitner, G. W. 1889. The Hunza and Nagyr Handbook. Pt. 1. Calcutta.

Liddell, H. G. and R. Scott (1968) [1897]. Greek-English Lexicon. Oxford: Clarendon Press.

Lorimer. D.L.R. 1935. The Burushaski Language. Vol. 1. Introduction and Grammar with a preface by G. Morgenstierne. Oslo: Institutet for Sammenlignende Kulturforskning. H. Aschehoug \& Co. 
1938. The Burushaski Language. Vol. 3. Vocabularies and Index. Oslo: Institutet for Sammenlignende Kulturforskning. H. Aschehoug \& Co.

- 1962. Werchikwar-English Vocabulary. Oslo: Norwegian Universities Press.

Mallory, J.P., Adams, D.Q. (eds.) 1997. Encyclopedia of IndoEuropean Culture. London - Chicago: Fitzroy Dearborn Publishers.

Mann, Stuart E. 1984-1987. An Indo-European Comparative Dictionary. Hamburg: Helmut Buske.

Mansoor et al. (2004). Investigation of the Greek ancestry of populations from northern Pakistan Human Genetics 114: 484490.

Morgensteirne, Georg. 1935. Preface to Lorimer (1935 I: vii-Xxx).

Neroznak, Vladimir. 1978. Paleobalkanskie jazyki. Moscow: Nauka. 1998. Foreword to Čašule (1998): ix-xiii.

Oefner, Peter J.; Hölzl, Georg; Shen, Peidong; Shpirer, Isaac, Gefek, Dov; Lavi, Tal; Wolf, Eilon; Cohen, Jonathan; Cinnioglu. Cengiz; Underhill, Peter A.; Rosenberge, Noah A.; Hochrein, Jochen; Granka, Julie M.; Hillel, Jossi and Feldman, Marcus W. 2013 Genetics and the history of the Samaritans: Ychromosomal microsatellites and genetic affinity between Samaritans and Cohanim. Human Biology Open Access PrePrints. Paper 40 : 825-857.

https://web.stanford.edu/group/rosenberglab/papers/OefnerEtAl 2013-HumBiol.pdf

Orel, Vladimir. 1997. The Language of Phrygians. New York: Caravan Books, Delmar.

Petrova, Eleonora, 1996. The Briges in the Central Balkans: $2^{\text {nd }}-1^{\text {st }}$ Millenium BC. (Bilingual Macedonian-English edition). Skopje: Museum of Macedonia.

Radenković, Lj. 2001. Lamja. In Tolstoj, S. M. and Lj. Radenković (eds.) Slovenska mitologija. Enciklopedijski rečnik. Beograd: Zepter Book World: 329-331. Rečnik na makedonskiot 
literaturen jazik. (I-III) 1961-1966. Skopje: Institut za makedonski jazik Krste Misirkov.

Schrader, O. 1901. Reallexikon der indogermanischen Altertumskunde. Strassburg.

Sidky, Homayun. 1999. Alexander the Great, the Graeco-Bactrians, and Hunza: Greek descents in Central Asia. Central Asiatic Journal 43/2: 232-248.

Steblin-Kamenskij, Ivan. M. 1999. Etimologičeskij slovar'vaxanskogo jazyka. St Petersburg: Peterburgskoe Vostokovedenie.

Steingass, Francis Joseph. 1999 [1892]. A Comprehensive PersianEnglish Dictionary, [orig. edition: London: Routledge \& K. Paul], reprint: Lahore: Sang-e-Meel Publications.

Szemerényi, O.J.L. 1996. Introduction to Indo-European Linguistics. Oxford: University Press.

Tiffou, Étienne and Yves-Charles Morin. 1993. Le Préfix $d$-en bourouchaski du Yasin. In Crochetière, André et al. (eds.). Endangered Languages. Proceedings of the XVth International Congress of Linguists, Quebec, Université Laval, 9-14 August 1992. Sainte-Foy, Canada: PU Laval.

Tiffou, É., Morin, Y.C. 1989. Dictionnaire complèmentaire du Bourouchaski du Yasin. AMI 17. SELAF 304. Paris: PEETERS/SELAF.

Tiffou, É, Pesot, J. 1989b. Contes du Yasin. (Introduction au bourouchaski du Yasin avec grammaire et dictionnaire analytique). Paris: PEETERS/SELAF.

Tiffou, É. (manuscript) Yasin Burushaski-French dictionary.

Tikkanen, Bertil.1999. Concerning the Typology of Burushaski and the Roots of Its Prefixes d- and n-. Studia Orientalia 85: 277300 .

Trubačev, Oleg N. 1974-. Etimologičeskij slovar' slavjanskix jazykov. Moskva: Nauka. 
1999. INDOARICA v Severnom Pričernomorie. (Rekonstrukcija reliktov jazyka; Etymologičeskij slovar'). Moskva: Nauka.

Watkins, Calvert. 2000. The American Heritage Dictionary of IndoEuropean Roots. ( $2^{\text {nd }}$ edition). Boston: Houghton Mifflin.

Willson, Stephen, R. 1999. Basic Burushaski Vocabulary. Studies in Languages of Northern Pakistan, Vol. 6. Islamabad: National Institute of Pakistan Studies/Summer Institute of Linguistics.

Zarubin, I. 1927. Veršikskoe narečie kandžutskogo jazyka. Kollegija vostokovedov. Zapiski 2: 275-364.

Zgusta, L. 1964. Kleinasiatische Personennamen. Prague.

Zoller, Claus Peter. 2010. Aspects of the Early History of Romani. Acta Orientalia 71: 49-83. 